\title{
(a) Effects of red wine on accelerated gastric OPEN ACCESS emptying following Nissen fundoplication
}

\author{
Qiqi Zhou, G Nicholas Verne
}

Department of Medicine, The University of Tennessee Health Science Center, Department of Medicine, Memphis, Tennessee, USA

\section{Correspondence to} Dr G Nicholas Verne, The University of Tennessee Health Science Center College of Medicine Memphis, Memphis, TN 38163, USA:

gverne@uthsc.edu

Accepted 21 May 2020

\section{Linked}

http://dx.doi.org/10 1136/jim-2020-001327

\section{Check for updates}

(C) American Federation for Medical Research 2020. Re-use permitted under CC BY-NC. No commercial re-use. Published by BMJ.

To cite: Zhou Q, Verne GN. J Investig Med 2020;68:951.
Alcohol consumption and the effects on the gastrointestinal tract are well known. The deleterious effects of alcohol leading to mortality are most apparent on the liver and pancreas. However, heavy alcohol consumption may have a significant impact on the luminal gastrointestinal tract. ${ }^{1}$ Alcohol consumption has the most significant effects on esophageal, gastric, and small intestinal motility as well as stimulating acid secretion and increasing intestinal permeability. ${ }^{2-4}$ Previous investigations have suggested that alcohol's effect on gastric and small bowel motility may be related to the absolute level of alcohol concentration. Low alcohol concentrations have been shown to accelerate gastric emptying whereas high doses of alcohol delay gastric emptying and slow small bowel motility and transit. ${ }^{56}$ The effects of acute and chronic alcohol administration on gastric emptying and small bowel transit have also been studied in rats. A high concentration of alcohol given in one large dose delayed gastric emptying and small bowel transit. ${ }^{7}$ Interestingly, in rats treated with large doses of alcohol for 10 consecutive days, gastric emptying did not change significantly, but small bowel transit was delayed.

In the current issue of the Journal of Investigative Medicine, Gonzalez et $a l^{8}$ present a provocative case study and an in-depth review of the published literature on the effects of alcohol and gastric motility. As noted by the authors, there are multiple factors that play a role in the effect of alcohol on gastric emptying that include alcohol concentration, caloric content, osmolarity, amino acids, as well as how the alcoholic beverage is produced, fermentation versus distillation. These various factors of alcohol consumption may indeed help to explain the differences in outcomes in previously published studies in both humans and animals. The authors also point out that chronic consumption of alcohol alters the myenteric nitrergic system resulting in impaired gastrointestinal motor function and inhibits the release of key neurotransmitters such as acetylcholine that drive gastrointestinal motility.

The current report evaluates a patient with symptoms suggestive of dumping syndrome following a Nissen fundoplication. The patient suffered from postprandial abdominal pain, bloating, nausea, vomiting and diarrhea. These symptoms along with $71 \%$ gastric emptying at 1 hour were consistent with dumping syndrome. Interestingly, the patient noted that consuming an 8-ounce glass of wine (Bogle Merlot, $14.5 \%$ alcohol) before and during meals, eliminated the dumping symptoms. The investigators confirmed this by measuring gastric emptying after the patient consumed a standard glass of wine and gastric emptying was normalized to $23 \%$ at 1 hour without any of the symptoms associated with dumping.
These interesting observations may be explained by impaired vagal function following fundoplication that led to the symptoms suggestive of dumping syndrome. The anticholinergic effect of alcohol was augmented in the setting of vagal nerve denervation that resulted in slowing of gastric emptying with subsequent alleviation of dumping symptoms. These interesting results need further validation in future controlled studies evaluating the effects of alcohol on gastric emptying before recommending alcohol for therapy of dumping syndrome resulting from a vagotomy or vagal nerve damage. However, these provocative findings if confirmed, may lead to other potential treatment options for patients with dumping syndrome.

Contributors Both authors wrote this editorial.

Funding Grant support: (DK099052 and DK118959) GNV and QZ; and the Department of Veterans Affairs (1101CX001477) QZ.

\section{Competing interests None declared.}

Patient consent for publication Not required.

Provenance and peer review Commissioned; internally peer reviewed.

Open access This is an open access article distributed in accordance with the Creative Commons Attribution Non Commercial (CC BY-NC 4.0) license, which permits others to distribute, remix, adapt, build upon this work non-commercially, and license their derivative works on different terms, provided the original work is properly cited, an indication of whether changes were made, and the use is non-commercial. See: http://creativecommons.org/licenses/ by-nc/4.0/.

\section{ORCID iD}

G Nicholas Verne http://orcid.org/0000-0001-9144-291X

\section{REFERENCES}

1 Stermer E. Alcohol consumption and the gastrointestinal tract. Isr Med Assoc J 2002;4:200-2.

2 Verne GN, Sninsky CA. Chronic intestinal pseudo-obstruction. Dig Dis 1995;13:163-81.

3 Addolorato G, Capristo E, Gasbarrini G, et al. Depression, alcohol abuse and orocaecal transit time. Gut 1997;41:417-8

4 Keshavarzian A, Fields JZ, Vaeth J, et al. The differing effects of acute and chronic alcohol on gastric and intestinal permeability. Am J Gastroenterol 1994;89:2205-11.

5 Bujanda $L$. The effects of alcohol consumption upon the gastrointestinal tract. Am J Gastroenterol 2000;95:3374-82.

6 Verne GN, Soldevia-Pico C, Robinson ME, et al. Autonomic dysfunction and gastroparesis in cirrhosis. J Clin Gastroenterol 2004:38:72-6.

7 Izbéki F, Wittmann T, Csáti S, et al. Opposite effects of acute and chronic administration of alcohol on gastric emptying and small bowel transit in rat. Alcohol Alcohol 2001;36:304-8.

8 Gonzalez Z, Herlihy D, Phan C, et al. Alcohol and gastric motility: pathophysiological and therapeutic implications. J Investig Med 2020;68:965-71. 